\title{
EKONOMICZNE ASPEKTY FUNKCJONOWANIA DRZEW W PRZESTRZENI MIEJSKIEJ - PRÓBA OCENY NA BAZIE WOLONTARIACKIEJ INFORMACJI GEOGRAFICZNEJ
}

\author{
ECONOMIC ASPECTS OF THE FUNCTIONING OF TREES \\ IN URBAN SPACE - AN ATTEMPT AT EVALUATION \\ ON THE BASIS OF VOLUNTARY GEOGRAPHIC INFORMATION
}

\begin{abstract}
Nr DOI: $10.25167 / \mathrm{sm} 2018.029 .07 \quad$ s. $101-114$
ABSTRAKT: Drzewa są dobrem wspólnym przynoszącym szereg korzyści środowiskowych, społecznych i ekonomicznych. Umiejętność rozpoznania dostarczanych usług ekosystemowych oraz ich wycena są niezbędne do zrozumienia prawdziwej wartości zieleni na terenach zurbanizowanych, która znacznie przewyższa wartość rynkową drewna jako surowca. Poza najważniejszymi pożytkami z funkcjonowania drzew w miastach, dzięki którym odnotowuje się oszczędności w budżetach miast oraz osób prywatnych, przytoczono koszty ponoszone przez instytucje publiczne zarządzające przestrzenią miast. Narzędziem do inwentaryzacji drzew, ich wyceny oraz wizualizacji danych jest wolontariacka informacja geograficzna, na której bazie powstały portale internetowe prezentujące korzyści funkcjonowania drzew w miastach.
\end{abstract}

SŁOWA KLUCZOWE: funkcje drzew, usługi ekosystemowe, wolontariacka informacja przestrzenna

ABSTRACT: Trees are universally considered a common good as they provide a host of environmental, social and economic benefits. The ability to quantify the provision of ecosystem services is essential to understanding the true value of trees in urban areas, which may, in fact, outweigh the market value of wood as a raw material. Apart from numerous advantages of trees functioning in cities, which generate savings to the budgets of cities and individuals, the article quotes the costs incurred by public authorities for managing the urban space. The tool for the valuation of trees as well as the visualization of relevant data is volunteered geographic information. Such information forms the basis for several Internet portals that seek to quantitatively demonstrate the benefits of functional trees in urban environments.

KEY WORDS: trees functions, ecosystems services, volunteered geographic information

* Uniwersytet Gdański, Wydział Oceanografii i Geografii, Katedra Geografii Fizycznej i Kształtowania Środowiska, e-mail: krystian.puzdrakiewicz@phdstud.ug.edu.pl. 


\section{Wprowadzenie}

Drzewa, występując w przestrzeni, posiadają pewną wartość ekonomiczną. Próby jej oszacowania odnoszą się bezpośrednio do samego drzewa albo do usług, jakie pełni wobec środowiska miejskiego i jego mieszkańców. Te pierwsze skupiają się na określeniu jego wartości rynkowej, przy czym głównie dotyczy to nowych nasadzeń lub drzew przeznaczonych do usunięcia. Druga grupa obejmuje usługi ekosystemowe, których oszacowanie jest trudniejsze i mniej precyzyjne, natomiast niezwykle ważne dla zrozumienia roli drzewa w przestrzeni miejskiej. Celem artykułu jest przedstawienie ekonomicznych korzyści i kosztów związanych z funkcjonowaniem drzew w tej przestrzeni. Za przykład inwentaryzacji i wyceny wartości usług ekosystemowych wzięto dwa portale internetowe wykorzystujące wolontariacką informację geograficzną, będące wartościowym zbiorem danych na temat miejskich drzewostanów.

\section{Ekonomiczne korzyści funkcjonowania drzew w mieście}

Ochrona środowiska jest specyficzną dziedziną w gospodarce krajowej, która wymaga finansowania, natomiast najczęściej nie przynosi bezpośredniego zysku z dokonanych inwestycji. Korzyści ekonomiczne odnotowuje się w innych sektorach gospodarki lub sferach życia publicznego, które dzięki dobremu stanowi środowiska wymagają mniejszych nakładów finansowych. Ze względu na częsty brak świadomości o pośrednich korzyściach ekonomicznych z funkcjonowania przyrody podejmowane są decyzje marginalizujące ochronę i kształtowanie systemu przyrodniczego miast, wprowadzające w zamian twarde rozwiązania infrastrukturalne lub wspierające rozwój gospodarczy.

Artykuł skupia uwagę na drzewach, ponieważ przynoszą one znacznie więcej korzyści niż inne rodzaje zieleni, takie jak krzewy czy powierzchnie trawiaste. Przechwytują one dwutlenek węgla i na trwałe wbudowują go w swoją tkankę. Dodatkowo są długowieczne, a ich rozmiary powodują wzrost intensywności świadczonych usług ekosystemowych. Proces sekwestracji $\mathrm{CO}_{2} \mathrm{u}$ drzew jest znacznie efektywniejszy niż w przypadku zieleni niskiej zajmującej tę samą powierzchnię terenu, a tempo gromadzenia węgla w tkankach zwiększa się wraz ze wzrostem drzewa (Szczepanowska, Sitarski 2015). Warto prześledzić szereg korzyści, jakie przynoszą drzewa, co jest szczególnie istotne w miastach, które charakteryzują się występowaniem wielu negatywnych zjawisk, takich jak zanieczyszczone powietrze, miejska wyspa ciepła czy spadek atrakcyjności przestrzeni przejawiający się np. obniżeniem wartości nieruchomości.

Jedną z najważniejszych korzyści funkcjonowania drzew w mieście jest ich wkład w poprawę jakości powietrza pod względem zarówno chemicznym, jak i fizycznym. W 2006 r. w Vancouver odbyło się Światowe Forum Urbanistyczne, na którym zgodnie uznano, że miasta najsilniej odczują efekty zmian klimatu i poniosą większość kosztów związanych z adaptacją do globalnego ocieplenia. Miasta emitują ok. 80\% gazów cieplarnianych. Wniosek z tego, że tereny zurbanizowane są zarówno największym źródłem, jak i największym odbiorcą zagrożeń związanych z podwyższaniem się tem- 
peratury (Cities and Climate Change... 2010; Montgomery 2015). W miastach odnotowuje się średniorocznie o ok. $1,5^{\circ} \mathrm{C}$ wyższą temperaturę niż na terenach podmiejskich. Różnica ta może osiągnąć wartość nawet $7^{\circ} \mathrm{C}$, biorąc pod uwagę poszczególne miesiące (Łukasiewicz, Łukasiewicz 2011). W efekcie, szczególnie w porze letniej, odnotowuje się wzrost zapotrzebowania na energię elektryczną do klimatyzowania pomieszczeń. Warto się przyjrzeć korzyściom ekonomicznym, jakie przynoszą drzewa pod względem energetycznym, nawet pomimo faktu, iż w Polsce systemy klimatyzacji nie są aż tak rozpowszechnione jak w Stanach Zjednoczonych (szczególnie biorąc pod uwagę domy prywatne). W USA lasy miejskie i zadrzewienia przynoszą oszczędności w wymiarze blisko 800 mln USD rocznie z powodu zmniejszenia zużycia energii na klimatyzację. Dodatkowo szacuje się, że odpowiednie rozmieszczenie zieleni wokół budynku może skutkować 30-procentowymi oszczędnościami na chłodzeniu i ok. 10-25-procentowymi na ogrzewaniu jego pomieszczeń (Kosmala 2007). Należy pamiętać, że zbiorowiska drzew oddziałują silniej od poszczególnych obiektów, co można zauważyć np. w parkach i lasach miejskich. Odnotowuje się tam niższe temperatury o odpowiednio 13,5\% i 20,3\% w stosunku do zurbanizowanej przestrzeni miasta (Łukasiewicz, Łukasiewicz 2011). Obszary zadrzewione oddziałują też w swoim najbliższym otoczeniu, co wzmaga ich walkę z ekstremalnymi zjawiskami termicznymi. Również zimą drzewa, szczególnie te iglaste, przyczyniają się do poprawy warunków termicznych miast. Zmniejszają prędkość wiatru, dzięki czemu budynki tracą mniej ciepła. Szerokie zastosowanie drzew w celu poprawy efektywności energetycznej zabudowy może skutkować redukcją wymaganej mocy cieplnej i energetycznej do zaspokojenia potrzeb społeczeństwa oraz ograniczeniem inwestycji związanych z funkcjonowaniem sieci np. w postaci stacji transformatorowych, elektrociepłowni czy kotłowni. Obniżenie kosztów klimatyzacji i ogrzewania wpłynie również na utrzymanie budynków.

Jakość powietrza pod względem chemicznym odnosi się do zawartości w nim związków chemicznych, które są szkodliwe dla organizmów żywych. Drzewa pełnią funkcję naturalnego filtra, który wytrąca lub przechwytuje część zanieczyszczeń. W okresie bezlistnym zanieczyszczenie powietrza pod koronami drzew zmniejsza się o 13-18\%, a w okresie ulistnienia o 20-40\%. Dla przykładu stuletni buk o wysokości ok. $25 \mathrm{~m}$ ma powierzchnię liści równą $1200 \mathrm{~m}^{2}$, która wiąże dziennie $15 \mathrm{~kg}$ dwutlenku węgla. W ciągu jednego sezonu takie drzewo neutralizuje składniki pochodzące ze spalenia ok. 1701 benzyny (Malczyk 2012). Nie ma aktualnie żadnych technicznych metod oczyszczania powietrza z pyłów, dlatego tak istotna jest rola roślin w kształtowaniu odpowiednich warunków środowiskowych. Dodatkowo drzewa wzbogacają powietrze w tlen, nawilżają je i wydzielają m.in. substancje bakteriobójcze - fitoncydy. Ekonomicznych korzyści wynikających z dobrej jakości powietrza można upatrywać w mniejszej zachorowalności ludzi, co ogranicza koszty związane ze służbą zdrowia i opieką społeczną. Ponadto dobry stan jakościowy atmosfery nie wymaga ponadstandardowych działań związanych z ochroną środowiska, co pozwala zaoszczędzić dodatkowe środki finansowe. Dotyczyć to może m.in. dodatkowych zabiegów pielęgnacyjnych roślin oraz ochrony zabytków niszczejących wskutek kwaśnych deszczy. 
Drzewa, regulując lokalny klimat, wpływają również na ograniczenie strat z powodu katastrof naturalnych, m.in. o charakterze hydrologicznym. Samo występowanie terenów zieleni ogranicza spływ powierzchniowy poprzez jego spowolnienie lub retencję wody. Drzewa ograniczają spływ wód opadowych o 12\% dzięki intercepcji przez ich nadziemne i podziemne części wraz z retencją glebową w ich otoczeniu (Szczepanowska 2015). Jest to pomocne w walce $\mathrm{z}$ podtopieniami czy powodziami, których powstawaniu sprzyjają tereny o dużym udziale powierzchni nieprzepuszczalnych wraz z ubogą szatą roślinną. Każda taka sytuacja wiąże się często z wielomilionowymi stratami zarówno w budżecie miasta, jak i w budżetach prywatnych osób. Gdyby miasto posiadało duży udział powierzchni biologicznie czynnych ${ }^{1}$, prawdopodobnie ograniczyłoby to konieczność inwestowania w rozbudowane, a tym samym kosztowne projekty infrastruktury technicznej, tj. kanalizacji burzowej czy zbiorników retencyjnych. Elementem zastępczym dla rozległych terenów zieleni są właśnie drzewa. Drzewa wspomagają miasto w odpowiednim zarządzaniu zasobami wodnymi, dlatego warto zwiększać ich liczbę w przestrzeni zurbanizowanej. Ponadto ograniczają koszty funkcjonowania innych rodzajów infrastruktury technicznej. Warto przytoczyć fakt, iż drzewa występujące w pasie drogowym powodują zacienienie jezdni, co wydłuża jej żywotność nawet o 200\% (Borowski 2009). To zaś przekłada się bezpośrednio na środki finansowe niezbędne do pokrycia remontów.

Jedną z ekonomicznych korzyści występowania drzew w mieście jest podnoszenie wartości nieruchomości. Przestrzeń w tym kontekście rozumiana jest jako zbiór cech, którym wartości są nadawane przez człowieka. Te wartości nie tkwią w istocie przestrzeni, ale są kreowane przez użytkowników rynku poprzez oceny cech charakteryzujących nieruchomość. Wartość rozumiana jest w postaci zewnętrznego wyrazu jakości przestrzeni. Użytkownicy przestrzeni poddają ją ocenie przez pryzmat cech oraz określają sumę potencjalnych korzyści osiągniętych dzięki zagospodarowaniu fragmentu przestrzeni, przy równoczesnej maksymalizacji tych korzyści. Zatem wartość nieruchomości jest wypadkową przewidywanych dochodów, które można generować w zależności od zagospodarowania przestrzeni (Hermann 2013).

Wartość rynkowa przestrzeni jest zróżnicowana ze względu na czynniki endogeniczne, czyli te charakteryzujące daną nieruchomość, i egzogeniczne, które tworzą otoczenie nieruchomości. Te pierwsze rozpatrywane są w ramach konkretnej działki i decydują o podaży tej przestrzeni. Drugie natomiast oddziałują jako suma rozwoju całego obszaru i należy do nich zaliczyć czynniki: ekonomiczne, prawne, społeczne i technologiczne. Czynniki endogeniczne fragmentu przestrzeni w konkretnych warunkach egzogenicznych kształtują wartość nieruchomości (Hermann 2013). Tereny miejskie, na których występują drzewa, podlegają różnego rodzaju zmianom ich war-

\footnotetext{
${ }^{1}$ Powierzchnie biologicznie czynne, aby być skutecznym narzędziem prowadzenia zrównoważonej gospodarki wodnej na terenach zurbanizowanych, muszą oprócz dużego udziału w ogólnej powierzchni miasta mieć uzasadnioną lokalizację, wynikającą z przestrzennej struktury terenów nieprzepuszczalnych i chłonnych.
} 
tości w zależności od czynników wewnętrznych i zewnętrznych. Sąsiedztwo terenów zadrzewionych wpływa na poprawę atrakcyjności otoczenia. Zieleń szczególnie mocno oddziałuje na tereny mieszkaniowe. Dodatkowo miejsca takie jak parki i zieleńce powodują wzrost atrakcyjności inwestycyjnej lokali usługowych znajdujących się $\mathrm{w}$ ich otoczeniu. Powstają w tych miejscach np. kawiarnie i restauracje, które cieszą się popularnością. To z kolei sprzyja wizerunkowi miejsca i buduje jego prestiż, co przekłada się na wzrost wartości nieruchomości. Należy mieć jednak na uwadze, że choć zyskuje otoczenie, to teren zieleni nie cechuje się wysoką wartością ekonomiczną ze względu na duże ograniczenia w zainwestowaniu. Coraz częściej nowe projekty osiedli mieszkaniowych czy nawet przestrzeni usługowych zakładają duży udział zieleni i rozwiązania proekologiczne. Ten słuszny kierunek w podejściu do kreowania przestrzeni przynosi różnego rodzaju korzyści. Po pierwsze liczne nasadzenia drzew i innego rodzaju roślinności mają pozytywny wpływ na wizerunek inwestycji i zwiększają popyt na te nieruchomości. Po drugie zwiększają komfort życia mieszkańców, a także pośrednio całej społeczności. Z kolei te atuty przekładają się na wzrost wartości nieruchomości i zyski inwestorów. Wprowadzenie drzew w obszarach zabudowanych wpływa pozytywnie na ogólną wartość przestrzeni. Według H.B. Szczepanowskiej (2009) drzewa stanowią wartość trwałą, pełniącą określone funkcje użytkowe na danym terenie, przez co są elementem tworzącym wartość użytkową nieruchomości. Ich uszkodzenia lub usunięcia są szkodą rzeczową, wpływającą bezpośrednio na wartość działki, co wymaga stosowania rekompensat poprzez wprowadzanie nasadzeń zastępczych lub w formie pieniężnej. Z drugiej strony należy zwrócić uwagę na liberalizację polskiego prawa w sprawie wycinki drzew z końca 2016 r. ${ }^{2}$, co spowodowało ich masowe usuwanie z działek prywatnych. W odczuciu właścicieli zwiększono w ten sposób atrakcyjność działki przeznaczonej do zainwestowania lub zmniejszono uciążliwości wynikające z występowania drzewa w danej lokalizacji. W przypadku działek już zagospodarowanych można się zgodzić z powyższym twierdzeniem autorki, gdyż drzewa są istotnym elementem aranżującym przestrzeń, co przekłada się na wartość ekonomiczną nieruchomości.

Należy też zwrócić uwagę na walory krajobrazowe i estetykę przestrzeni, które są determinantami wcześniej wymienianej jakości lokalizacji. To one są w gronie najważniejszych wyróżników wartości nieruchomości mieszkaniowych i związanych z wypoczynkiem (ośrodki wypoczynkowe, hotele, restauracje). Otoczenie m.in. terenami zadrzewionymi wpływa na odbiór i wartość przestrzeni (Senetra 2010). Ceny rynkowe terenów charakteryzujących się atrakcyjnym krajobrazem wzrastają nawet o 30\%. Z drugiej strony nabywcy mieszkań z widokiem na tereny zadrzewione są w stanie zapłacić o 15\% więcej za taką nieruchomość (Szczepanowska 2012). Badanie przeprowadzone przez A. Zydronia i współpracowników (2016), choć dotyczy terenu

2 Ustawa z dnia 16 grudnia 2016 r. o zmianie ustawy o ochronie przyrody oraz ustawy o lasach, Dz.U. z 2016 r., poz. 2249. 
gminy wiejskiej, wykazało, iż jednym z głównych czynników wpływających na wartość nieruchomości przeznaczonych na cele budowlane jest odległość od terenów leśnych. Potwierdza to tezę, że wartość nieruchomości wzrasta odwrotnie proporcjonalnie do odległości od terenów zieleni lub innych elementów środowiska przyrodniczego. Szczególnie widoczne jest to na obszarach miejskich, gdzie występuje deficyt terenów naturalnych i seminaturalnych. Dodatkowo pozytywny wpływ zieleni odnotowuje się w handlu. Ludzie odwiedzający tereny handlowe zlokalizowane w sąsiedztwie ulic zadrzewionych i w zadbanym krajobrazie twierdzą, że zapłacą o 9-12\% wyższe ceny piętnastu podstawowych produktów niż w miejscach pozbawionych elementów roślinnych (Wolf 2006).

\section{Koszty funkcjonowania drzew w mieście}

Drzewa pomimo tego, że przynoszą szereg korzyści ekonomicznych, wymagają finansowania zarówno na etapie projektowania i zagospodarowania przestrzeni, jak i dalszego funkcjonowania. Skoro drzewa występują w konkretnej przestrzeni, to ograniczają możliwości jej zagospodarowania. Miasto zatem posiada tereny takie jak: pasy przydrożne, parki, zieleńce, lasy miejskie, które nie generują bezpośrednich przychodów, np. w postaci podatku od nieruchomości, oraz utrudniają sprzedaż działek ze względu na zmniejszony zakres możliwości inwestycyjnych. Tu należy pamiętać o wzroście wartości działek sąsiednich, niemniej miejskie tereny zieleni generują koszty ich funkcjonowania i inwestycji. Kolejną sprawą jest utrzymanie drzew. Wymagają one m.in. szczególnej opieki w pierwszych latach od nasadzenia, takiej jak systematyczne cięcia pielęgnacyjne. Należy uprzątnąć drogę po obłamanych gałęziach, a jesienią usuwać opadnięte liście. To wszystko wymaga konkretnych nakładów finansowych, przewidzianych w budżecie miasta. Utrzymanie zieleni miejskiej w budżetach miast wojewódzkich w Polsce w roku 2016 kosztowało w sumie ponad 258,10 mln zł, przy średnim wyniku 14,34 mln zł na stolicę województwa. Największe wydatki ogółem poniesiono: we Wrocławiu (50,55 mln zł), w Łodzi (29,57 mln zł), w Poznaniu (26,70 mln zł) oraz w Krakowie (26,35 mln zł), natomiast najmniejsze koszty utrzymania zieleni odnotowano w: Toruniu (32,15 tys. zł), Gorzowie Wielkopolskim (2,95 mln zł), Opolu (3,07 mln zł) i Zielonej Górze (3,66 $\mathrm{mln}$ zł). Biorąc pod uwagę wydatki ogółem miast wojewódzkich, na utrzymanie zieleni przeznaczono średnio 0,61\% całorocznego budżetu. Największy udział w wydatkach ogółem odnotowano w Katowicach (1,36\%), Wrocławiu (1,28\%) oraz Rzeszowie (1,12\%). Koszt utrzymania $1 \mathrm{~m}^{2}$ zieleni miejskiej wyniósł średnio 0,74 zł, a największe koszty poniosły samorządy: Rzeszowa $\left(1,76 \mathrm{zł} / \mathrm{m}^{2}\right)$, Katowic $\left(1,75 \mathrm{zł} / \mathrm{m}^{2}\right)$ i Wrocławia $(1,62 \mathrm{zł} /$ $\mathrm{m}^{2}$ ). Pełne zestawienie dla wszystkich miast wojewódzkich prezentuje tabela 1 . W skład powyższych wydatków wchodzą zarówno działania dotyczące drzew, jak również inne usługi i inwestycje związane $\mathrm{z}$ terenami zieleni. Powyższe kwoty są zatem znacznie większe niż te dotyczące faktycznej opieki nad drzewostanem, natomiast pomagają zobrazować koszty funkcjonowania zieleni w mieście jako ogółu. Częstą praktyką jednostek zarządzających zielenią w miastach jest zlecanie kompleksowej opieki nad 
terenami zieleni zewnętrznym przedsiębiorstwom, co utrudnia określenie faktycznych kosztów poniesionych wobec drzew w przestrzeni publicznej.

Koszty utrzymania zieleni w miastach wojewódzkich w 2016 r.

\begin{tabular}{|c|c|c|c|c|}
\hline Lp. & Miasto wojewódzkie & $\begin{array}{c}\text { Wydatki } \\
\text { na utrzymanie zieleni }\end{array}$ & $\begin{array}{c}\text { Udział w ogóle } \\
\text { wydatków budżetu } \\
\text { miasta (\%) }\end{array}$ & $\begin{array}{l}\text { Koszt utrzymania } \\
\text { zieleni miejskiej }{ }^{a} \\
\left(\mathrm{z} \mathrm{z} / \mathrm{m}^{2}\right)\end{array}$ \\
\hline 1 & Wrocław & 50550985 & 1,28 & 1,62 \\
\hline 2 & Łódź & 29573003 & 0,77 & 0,77 \\
\hline 3 & Poznań & 26695506 & 0,83 & 0,60 \\
\hline 4 & Kraków & 26345524 & 0,56 & 1,06 \\
\hline 5 & Warszawa & 24382846 & 0,18 & 0,50 \\
\hline 6 & Katowice & 21901251 & 1,36 & 1,75 \\
\hline 7 & Szczecin & 12938504 & 0,64 & 0,37 \\
\hline 8 & Gdańsk & 12620933 & 0,47 & 0,56 \\
\hline 9 & Rzeszów & 11142486 & 1,12 & 1,76 \\
\hline 10 & Bydgoszcz & 7342724 & 0,43 & 0,38 \\
\hline 11 & Lublin & 7023296 & 0,38 & 0,51 \\
\hline 12 & Białystok & 6948576 & 0,46 & 0,66 \\
\hline 13 & Kielce & 5759088 & 0,50 & 0,97 \\
\hline 14 & Olsztyn & 5110031 & 0,56 & 0,28 \\
\hline 15 & Zielona Góra & 3662435 & 0,53 & 0,40 \\
\hline 16 & Opole & 3072689 & 0,42 & 0,53 \\
\hline 17 & Gorzów Wlkp. & 2949708 & 0,49 & 0,55 \\
\hline 18 & Toruń & 32154 & $0,00^{\mathrm{b}}$ & $0,00^{\mathrm{c}}$ \\
\hline \multicolumn{2}{|c|}{ Wartości średnie } & 14336208 & 0,61 & 0,74 \\
\hline
\end{tabular}

a Suma powierzchni terenów zieleni miejskiej, za które uznano: parki, zieleńce, zieleń uliczną, zieleń osiedlową, cmentarze, lasy gminne; b Udział procentowy w ogóle wydatków budżetu miasta Torunia wynosi 0,0032\%; c Koszt utrzymania zieleni w przeliczeniu na liczbę metrów kwadratowych zieleni miejskiej w Toruniu wynosi 0,0028 zł/ $\mathrm{m}^{2}$.

Źródło: opracowanie własne na podstawie danych GUS: https://bdl.stat.gov.pl/BDL/start (dostęp 21 marca 2018).

\section{Przykłady szacowania wartości usług ekosystemowych przy wykorzystaniu wolontariackiej informacji geograficznej}

Formą aktywnego uczestnictwa ludności w pozyskiwaniu informacji na zasadzie wolontariatu jest crowdsourcing. Jest to również forma partycypacji społecznej w odniesieniu do prowadzenia polityki przestrzennej. Ludzie dobrowolnie przesyłają informacje za pomocą Internetu, dzięki czemu współuczestniczą w budowaniu bazy danych. Są to osoby niezwiązane bezpośrednio z projektem i niekoniecznie są specjalistami w danej 
dziedzinie wiedzy. Należy mieć na uwadze, że choć jest to tani sposób pozyskiwania informacji, to nie ma pewności co do ich wiarygodności. Z drugiej strony można przypuszczać, że osoby zaangażowane w projekt są zainteresowane podejmowaną tematyką i posiadają odpowiednią wiedzę i umiejętności do pozyskiwania danych. Opublikowane dane mogą być również weryfikowane przez innych użytkowników. Jeżeli pozyskane informacje wymagają ich umiejscowienia w przestrzeni geograficznej, to wykorzystuje się do tego geograficzne systemy informacyjne (ang. Geographic Information System - GIS). Połączenie crowdsourcingu i GIS nosi nazwę wolontariackiej informacji geograficznej (ang. Voluntereed Geographic Information - VGI).

W przypadku określania ekonomicznych korzyści funkcjonowania drzew w mieście najbardziej pożądanymi danymi są: gatunek drzewa, obwód jego pnia (mierzony na wysokości ok. $130 \mathrm{~cm}$ od ziemi) oraz lokalizacja. Ze względu na to, że wymienione dane nie wymagają specjalistycznej wiedzy od osoby je pozyskującej, a możliwość popełnienia błędu jest niewielka lub jego wpływ na ogólny wynik jest nieznaczny, idealnym rozwiązaniem do gromadzenia informacji jest wykorzystanie wolontariackiej informacji geograficznej. Dzięki temu można tanio i szybko pozyskać dane o drzewach, które mogą się znajdować na bardzo dużym terenie. Taka forma partycypacji może pozytywnie wpłynąć na postawę społeczeństwa wobec ochrony środowiska, np. poprzez wzrost świadomości ekologicznej. Konkretne liczby wyrażające korzyści ekonomiczne z funkcjonowania drzew w mieście bardziej przemawiają do ludzi niż ogólne stwierdzenia - takie jak poprawa jakości powietrza czy obniżanie temperatury podczas letnich upałów. Wyliczenie wartości usług ekosystemowych drzew jest bardzo dobrym sposobem na zwrócenie uwagi mieszkańców oraz włodarzy miast na korzyści, jakie płyną z posiadania zieleni na obszarach zurbanizowanych. Może to być znaczącym argumentem w podejmowaniu polityk miejskich, ochrony aktualnie posiadanego drzewostanu i przyszłego kształtowania przestrzeni.

Dobrymi przykładami prezentującymi powyższy sposób pozyskiwania danych są portale internetowe Open Tree Map oraz NYC Street Tree Map. Ten pierwszy obsługuje 34 miasta/regiony: w Stanach Zjednoczonych (26), Kanadzie (5), Wielkiej Brytanii (1), Indiach (1) i Meksyku (1). Drugi natomiast jest poświęcony wyłącznie miastu Nowy Jork w Stanach Zjednoczonych. W tabeli 2 przedstawiono spis portali internetowych wchodzaccych w skład Open Tree Map oraz NYC Street Tree Map ${ }^{3}$.

Liczba zinwentaryzowanych drzew na poszczególnych obszarach jest mocno zróżnicowana. Zależy to przede wszystkim od popularności projektu wśród lokalnej społeczności oraz czasu funkcjonowania portalu. Najlepsze rezultaty osiągnięto w: Los Angeles, Nowym Jorku, Edmonton, Seattle i San Francisco, gdzie zinwentaryzowano łącznie niemal 2 mln drzew. Przyglądając się zdjęciom satelitarnym z naniesionymi punktami

\footnotetext{
3 W Polsce istnieje jeden przykład zastosowania wolontariackiej informacji geograficznej w odniesieniu do drzew. Serwis „Mapa Drzew” powstał dla Warszawy i jest tworzony w ramach społeczności Koduj dla Polski. Prezentowane są podstawowe informacje o 139361 drzewach, jednakże brak wyceny świadczonych usług ekosystemowych (http://www.mapadrzew.pl/warszawa/map/).
} 
Portale internetowe przeznaczone do wyceny usług ekosystemowych drzew w wybranych miastach lub regionach

\begin{tabular}{|c|c|c|c|c|c|}
\hline Lp. & Nazwa portalu & Obszar & $\begin{array}{l}\text { Liczba drzew } \\
\text { opisanych }^{\mathrm{a}}\end{array}$ & $\begin{array}{l}\text { Liczba drzew } \\
\text { ujęta w obli- } \\
\text { czeniach }^{\mathrm{b}}\end{array}$ & $\begin{array}{l}\text { Roczne } \\
\text { korzyścic }^{\mathrm{c}}\end{array}$ \\
\hline 1 & TreeMap LA & $\begin{array}{l}\text { Los Angeles / Stany } \\
\text { Zjednoczone }\end{array}$ & 783946 & 761804 & 27637074 \\
\hline 2 & $\begin{array}{l}\text { New York City Street } \\
\text { Tree Map }\end{array}$ & $\begin{array}{l}\text { Nowy Jork / Stany Zjed- } \\
\text { noczone }\end{array}$ & 683504 & - & 111130315 \\
\hline 3 & yegTreeMap & Edmonton / Kanada & 267500 & 231248 & 30824409 \\
\hline 4 & Seattle Tree Map & $\begin{array}{l}\text { Seattle / Stany Zjedno- } \\
\text { czone }\end{array}$ & 126804 & - & - \\
\hline 5 & $\begin{array}{l}\text { San Francisco Urban } \\
\text { Forest Map }\end{array}$ & $\begin{array}{l}\text { San Francisco / Stany } \\
\text { Zjednoczone }\end{array}$ & 126548 & 125577 & 2362474 \\
\hline 6 & Modesto Urban Forest & $\begin{array}{l}\text { Modesto / Stany Zjed- } \\
\text { noczone }\end{array}$ & 82040 & 934 & 2562696 \\
\hline 7 & PhillyTreeMap & $\begin{array}{l}\text { Philadelphia / Stany } \\
\text { Zjednoczone }\end{array}$ & 58137 & 31755 & 9896263 \\
\hline 8 & Treezilla & Wielka Brytania & 50872 & - & $3975918^{d}$ \\
\hline 9 & $\begin{array}{l}\text { TreeFolks Austin Tree } \\
\text { Map }\end{array}$ & $\begin{array}{l}\text { Austin / Stany Zjedno- } \\
\text { czone }\end{array}$ & 41534 & 38433 & 1068760 \\
\hline 10 & Claremont & $\begin{array}{l}\text { Claremont / Stany Zjed- } \\
\text { noczone }\end{array}$ & 24874 & 22778 & 767274 \\
\hline 11 & $\begin{array}{l}\text { Grand Rapids Urban } \\
\text { Forest Project }\end{array}$ & $\begin{array}{l}\text { Grand Rapids / Stany } \\
\text { Zjednoczone }\end{array}$ & 18701 & - & - \\
\hline 12 & Tampa Tree Map & $\begin{array}{l}\text { Tampa / Stany Zjedno- } \\
\text { czone }\end{array}$ & 17670 & 15157 & 2422774 \\
\hline 13 & Delaware Tree Map & $\begin{array}{l}\text { Wilmington / Stany } \\
\text { Zjednoczone }\end{array}$ & 13549 & 11948 & 595240 \\
\hline 14 & PA Tree Map & $\begin{array}{l}\text { Pensylwania / Stany } \\
\text { Zjednoczone }\end{array}$ & 12474 & 11834 & 975924 \\
\hline 15 & My Arboretum & $\begin{array}{l}\text { Utah / Stany Zjedno- } \\
\text { czone }\end{array}$ & 8248 & 4. 999 & 101825 \\
\hline 16 & Rhody Trees & $\begin{array}{l}\text { Newport / Stany Zjed- } \\
\text { noczone }\end{array}$ & 7546 & 6922 & 482367 \\
\hline 17 & Asheville Tree Map & $\begin{array}{l}\text { Asheville / Stany Zjed- } \\
\text { noczone }\end{array}$ & 6430 & 474 & 355143 \\
\hline 18 & Carson City & $\begin{array}{l}\text { Carson City / Stany } \\
\text { Zjednoczone }\end{array}$ & 5809 & 4562 & 145545 \\
\hline 19 & $\begin{array}{l}5 \text { Trees For Me City of } \\
\text { Frederick }\end{array}$ & $\begin{array}{l}\text { Frederick / Stany Zjed- } \\
\text { noczone }\end{array}$ & 5202 & 4919 & 182560 \\
\hline 20 & Openlands & $\begin{array}{l}\text { Chicago / Stany Zjed- } \\
\text { noczone }\end{array}$ & 3488 & 3388 & 23290 \\
\hline
\end{tabular}


Tabela $2 \mathrm{~cd}$

\begin{tabular}{|c|c|c|c|c|c|}
\hline Lp. & Nazwa portalu & Obszar & $\begin{array}{l}\text { Liczba drzew } \\
\text { opisanych }^{\mathrm{a}}\end{array}$ & $\begin{array}{l}\text { Liczba drzew } \\
\text { ujęta w obli- } \\
\text { czeniach }^{\text {b }}\end{array}$ & $\begin{array}{l}\text { Roczne } \\
\text { korzyści }^{\mathrm{c}}\end{array}$ \\
\hline 21 & Augusta University & $\begin{array}{l}\text { Augusta / Stany Zjed- } \\
\text { noczone }\end{array}$ & 2682 & 2517 & 72949 \\
\hline 22 & Hamilton Naturalists' & Hamilton / Kanada & 2565 & 1947 & 231416 \\
\hline 23 & Greenprint Maps & $\begin{array}{l}\text { Sacramento / Stany } \\
\text { Zjednoczone }\end{array}$ & 2347 & 2240 & 218258 \\
\hline 24 & Jersey City Tree Map & $\begin{array}{l}\text { Jersey City / Stany Zjed- } \\
\text { noczone }\end{array}$ & 2099 & 1485 & 149409 \\
\hline 25 & Alameda County & $\begin{array}{l}\text { Hayward / Stany Zjed- } \\
\text { noczone }\end{array}$ & 2044 & 1655 & 37371 \\
\hline 26 & Kawartha Lakes & $\begin{array}{l}\text { Kawartha Lakes / } \\
\text { Kanada }\end{array}$ & 1445 & 1131 & 117121 \\
\hline 27 & Arlington & $\begin{array}{l}\text { Arlington / Stany Zjed- } \\
\text { noczone }\end{array}$ & 1235 & 780 & 95317 \\
\hline 28 & URI Trees & $\begin{array}{l}\text { Kingston / Stany Zjed- } \\
\text { noczone }\end{array}$ & 1091 & 857 & 76988 \\
\hline 29 & $\begin{array}{l}\text { Great Ecology Ottawa } \\
\text { Tree Map }\end{array}$ & Ottawa / Kanada & 987 & 586 & 104050 \\
\hline 30 & San Diego Tree Tracker & $\begin{array}{l}\text { San Diego / Stany Zjed- } \\
\text { noczone }\end{array}$ & 797 & 767 & 1598 \\
\hline 31 & myTree Baton Rouge & $\begin{array}{l}\text { Baton Rouge / Stany } \\
\text { Zjednoczone }\end{array}$ & 371 & 69 & 25309 \\
\hline 32 & Chennai & Chennai / Indie & 237 & - & - \\
\hline 33 & $\begin{array}{l}\text { Toronto Ravine Revitali- } \\
\text { zation Study }\end{array}$ & Toronto / Kanada & 166 & 161 & - \\
\hline 34 & Bosque Urbano Potosino & $\begin{array}{l}\text { San Luis Potosí / } \\
\text { Meksyk }\end{array}$ & 75 & - & - \\
\hline 35 & Nebraska & $\begin{array}{l}\text { Nebraska / Stany Zjed- } \\
\text { noczone }\end{array}$ & 0 & 0 & 0 \\
\hline
\end{tabular}

Opis: Kolorem szarym oznaczono portal internetowy NYC Street Tree Map, pozostałe pozycje pochodzą z portalu Open Tree Map. a Liczba w pełni opisanych drzew (gatunek, obwód pnia, lokalizacja); b Liczba drzew, dla których obliczono wartość usług ekosystemowych; c Wartość korzyści usług ekosystemowych w przeliczeniu na jeden rok podana w dolarach amerykańskich; d Wartość przeliczona z funtów brytyjskich na dolary amerykańskie według kursu z dnia 15 lutego 2015 r., tj. 1 GBP = 1,2479 USD.

Źródło: opracowanie własne na podstawie: https://www.opentreemap.org/; https://tree-map.nycgovparks.org.

drzew, można zauważyć, że nie są to spisy skończone, posiadające kompletne dane. Wniosek z tego, iż ekonomiczna wartość korzyści z funkcjonowania drzew jest faktycznie znacznie większa, niż to wyliczono na podstawie dotychczasowej inwentaryzacji. Powodem wyraźnie widocznych różnic w rocznych wartościach korzyści obliczanych na podstawie podobnej liczby drzew (tak jak w przypadku miasta Wilmington i stanu 
Pensylwania) mogą być odmienne składy gatunkowe oraz wielkość poszczególnych obiektów w porównywanych drzewostanach.

Warto przyjrzeć się konkretnym miastom i portalom je obsługującym. W Nowym Jorku zorganizowano wielką akcję liczenia i inwentaryzowania drzew w 2015 r. Wolontariusze zostali wyposażeni w aplikacje mobilne służące do określania położenia geograficznego drzew i uzupełniania odpowiednich informacji o nich. Dzięki temu bardzo szybko i tanio zbudowano bazę danych liczącą prawie 800 tys. pozycji. Według informacji podanej na stronie internetowej jest to pełen spis drzew w granicach administracyjnych miasta. Spis ten obejmuje wyłącznie drzewa znajdujące się w pasach drogowych, zatem nie uwzględnia się w nim drzew rosnących w parkach miejskich lub innych przestrzeniach publicznych i prywatnych. Jest to dobrze widoczne na przykładzie dzielnicy Manhattan, gdzie obszar, na którym znajduje się Central Park, jest strefą pozbawioną jakichkolwiek danych. W Nowym Jorku obliczono, że suma ekonomicznych korzyści z funkcjonowania zinwentaryzowanych drzew wynosi 111129875 USD/ $\operatorname{rok}^{4}$. Z tego ok. $85 \mathrm{mln}$ USD (79,6\%) rocznie miasto oszczędza na produkcji energii, co jest efektem przede wszystkim poprawy jego warunków termicznych. W ciągu roku drzewa redukują zużycie energii o ponad $674 \mathrm{mln} \mathrm{kWh}$. Kolejno prawie $11 \mathrm{mln}$ USD (10,2\%) oszczędności w ciągu roku pochodzi z przechwyconej przez drzewa wody opadowej i roztopowej, ponieważ miasto nie musi m.in. inwestować w twarde rozwiązania infrastrukturalne. Drzewa odciążają kanalizację burzową miasta Nowy Jork o ponad $4 \mathrm{mln} \mathrm{m}^{3}$ wody w ciągu roku. Następnie ok. $7 \mathrm{mln}$ USD (6,3\%) rocznie oszczędności powoduje działalność drzew w sferze oczyszczania powietrza z pyłów. W ciągu roku są one w stanie związać 644 tony zanieczyszczeń. Na koniec - drzewa przynoszą ponad 4 mln USD $(3,9 \%)$ rocznie, redukując dwutlenek węgla z powietrza w wymiarze 627 tys. ton/rok (https://tree-map.nycgovparks.org/). Suma korzyści funkcjonowania drzew w pasie drogowym daje roczne oszczędności na poziomie 0,19\% ogółu wydatków w budżecie Nowego Jorku (https://opendata.cityofnewyork.us/). Miasto przeznaczyło w 2016 r. 307 mln USD (0,53\% ogółu wydatków) na utrzymanie parków i rekreację, co obejmuje szerszy zakres działalności miasta poza utrzymaniem drzew (The Fiscal Year 2015 Executive Budget).

Portal internetowy jest skonstruowany tak, aby każdy internauta mógł z łatwością odnaleźć odpowiednie drzewo i dowiedzieć się, jakie korzyści przynosi ono miastu. Na mapie zlokalizowane są symbole, których wielkość odnosi się do rozmiarów drzewa,

\footnotetext{
${ }^{4}$ Wycena usług ekosystemowych drzew polega na oszacowaniu ekonomicznej wartości dostarczanych korzyści, które można zmierzyć na podstawie znanych cen rynkowych dla uzyskania podobnych usług. Każda wycena powinna uwzględniać lokalne uwarunkowania. A. Bernaciak i M. Wojcieszak (2014) przyjęli dla warunków polskich następujące wartości jednostkowe: 14,00 zł za $1 \mathrm{~kg}$ wyprodukowanego tlenu (cena tlenu medycznego), 0,02 zł za $1 \mathrm{~kg}$ pochłoniętego $\mathrm{CO}_{2}$ (cena europejskiego certyfikatu redukcji emisji dla rynku polskiego), $0,02 \mathrm{zł} \mathrm{za} 1 \mathrm{~m}^{3}$ retencjonowanej wody (cena przepompowania $1 \mathrm{~m}^{3}$ wody pompą wodną). Zaproponowane przeliczniki wykorzystuje się do spieniężenia usług ekosystemowych, obliczonych na podstawie danych dotyczących obiektu (w zależności od wielkości, gatunku i kondycji drzewo dostarcza usługi o różnej intensywności).
} 
a barwa do jego gatunku. Po kliknięciu na odpowiedni symbol ukazuje się jego szczegółowy opis: nazwa gatunku, przypisany numer ID, obwód pnia, zdjęcie liścia drzewa w tym gatunku, najbliższy adres, obraz z Google Street View oraz wartości usług ekosystemowych. Każdy dzięki temu może sprawdzić, ile korzyści przynoszą np. drzewa zlokalizowane w jego najbliższym otoczeniu.

Sam portal Open Tree Map jest główną stroną projektu, natomiast każde miasto/ region posiada własną stronę internetową. Pozytywnym przykładem jest San Francisco, gdzie zinwentaryzowano dużą liczbę drzew. Dzięki ok. 125 tys. drzew miasto zaoszczędza rocznie 2362 474 USD. Najwięcej korzyści przynoszą one w ramach oszczędzania energii, ograniczając jej zużycie o prawie $13 \mathrm{mln} \mathrm{kWh}$, co daje niemal 1,3 mln USD (54,1\%) oszczędności rocznie. Oczyszczanie wód opadowych w wymiarze ok. 386 tys. $\mathrm{m}^{3}$ daje ponad 400 tys. USD (17,3\%) rocznych oszczędności. Kolejno drzewa poprawiają jakość powietrza usuwając 25 ton zanieczyszczeń w ciągu roku, co daje dodatkowe 340 tys. USD/rok (14,4\%). Następnie usuwają rocznie 8,8 tys. ton dwutlenku węgla z atmosfery przynosząc ponad 334 tys. USD (14,2\%) oszczędności. Dodatkowo portal podaje informacje o ilości dwutlenku węgla usuniętego od rozpoczęcia projektu (https://www.opentreemap.org/). Oszczędności wynikające z funkcjonowania drzew stanowią 0,02\% wydatków ogółem budżetu miasta. Całkowity koszt utrzymania drzew wyniósł 11979812 USD w roku fiskalnym 2016-2017. Choć ponoszone koszty są kilkakrotnie większe od szacowanej wartości usług ekosystemowych, to należy pamiętać, że inwentaryzacja drzew jest niepełna i ten stosunek w rzeczywistości jest korzystniejszy (Annual urban forest report... 2017).

Choć w wypadku Open Tree Map symbolizacja drzew na mapie jest jednakowa dla wszystkich obiektów, to istnieje możliwość sprawdzenia szczegółów dotyczących konkretnego drzewa. Mogą się w tym miejscu znajdować informacje m.in. na temat: gatunku, wysokości, obwodu pnia, daty posadzenia oraz usunięcia, stanu, w jakim drzewo się znajduje, szerokości korony, występowania linii energetycznych, adresu oraz usług ekosystemowych. Na ogół wypełnione są wyłącznie podstawowe dane, tj.: gatunek, grubość pnia i stan oraz wyliczone wartości dla usług ekosystemowych. W odróżnieniu do NYC Street Tree Map Open Tree Map uwzględnia drzewa znajdujące się w przestrzeni publicznej poza pasem drogowym. Plusem takiego rozwiązania jest możliwość pełniejszej inwentaryzacji drzew i obliczenia bardziej prawdopodobnych korzyści wynikających z usług ekosystemowych. W portalu nie zamieszcza się drzew znajdujących się na terenach prywatnych lub innych roślin, przez co suma wspomnianych korzyści nigdy nie będzie całkowita.

Ze względu na przyjęte rozwiązanie pozyskiwania danych za pomocą crowdsourcingu inwentaryzacja drzewostanu musi być uproszczona, przez co niedokładna. Dane dotyczące gatunku, obwodu pnia oraz lokalizacji mogą być w większości przypadków niewystarczające, gdyż na ogół znaczna część drzew posiada pewne zniekształcenia korony lub charakteryzuje się gorszym stanem zdrowotnym bądź zachowania w stosunku do modelu drzewa idealnego, wynikającego z powyższych danych podstawowych. Konieczne jest stosowanie współczynnika kondycji drzew, który skoryguje dane 
wyjściowe, natomiast wymaga on inwentaryzacji przez osobę z odpowiednią wiedzą na temat oceny drzew. Jednakże takie podejście utrudnia zbieranie danych, wiązałoby się z ograniczeniem liczby zinwentaryzowanych obiektów lub poniesieniem znacznych kosztów wynajęcia profesjonalnych badaczy do kompleksowej oceny miejskich drzewostanów. Przyjęte rozwiązanie, choć niedokładne, daje możliwość uzyskania tanio i szybko informacji na temat korzyści wynikających z funkcjonowania drzew w przestrzeni miejskiej, przy dodatkowym wzroście świadomości ekologicznej społeczeństwa, co jest niewątpliwym walorem jego stosowania.

\section{Podsumowanie}

Przestrzeń miejska nie może prawidłowo funkcjonować bez systemu zieleni, którego głównym komponentem są drzewa. Korzyści z ich funkcjonowania są wielopłaszczyznowe, przez co wymagają one ochrony i determinują powiększanie zasobów drzewostanów miejskich. Świadomość wartości dostarczanych przez drzewa usług ekosystemowych jest niezbędna do powyższych działań. Aspekty środowiskowe, społeczne i ekonomiczne przemawiają za stosowaniem drzew do kształtowania odpowiednich warunków środowiska miejskiego, przez co wzrasta jakość życia mieszkańców. Pomimo niezbędnych kosztów ponoszonych na utrzymanie zieleni warto inwestować w drzewa, których wartości usług wielokrotnie przekraczają poniesione wydatki ${ }^{5}$. $\mathrm{Na}$ zaprezentowanych przykładach użycia wolontariackiej informacji geograficznej widać, że możliwe jest pozyskiwanie niezbędnych danych do zarządzania zasobami przestrzeni w zakresie zieleni miejskiej przy wykorzystaniu bezkosztowych metod. Miejskie jednostki zajmujące się zielenią dostają w ten sposób cenne informacje, a społeczeństwo i przede wszystkim władze miast dostają konkretne argumenty do ochrony i kształtowania systemów zieleni miejskiej poprzez spieniężone wartości usług ekosystemowych. Niedokładności wynikające z uproszczonego modelu inwentaryzacji drzew mogą być istotne w wycenie prawidłowych wartości dostarczanych usług, ale biorąc pod uwagę aspekt społeczny i wkład w zasób informacji o elementach przestrzeni miejskiej, ocenia się pozytywnie działania pozyskiwania i prezentacji danych o drzewach za pomocą wolontariackiej informacji geograficznej.

\section{Bibliografia}

Annual urban forest report. Fiscal year July 2016 - June 2017, 2017, Urban Forestry Council, s. 18.

Bernaciak A., Wojcieszak M., 2014, The valuation of trees in the urbanized areas with the compensation/replacement method and benefits analysis (the case of the city of Gniezno), „Economics and Environment” 4(51).

Borowski J., 2009, Dlaczego warto sadzić i pielęgnować drzewa?, [w:] Worobiec K.A., Liżewska I. (red.), Aleje przydrożne. Historia, znaczenie, zagrożenie, ochrona, Stowarzyszenie na rzecz Ochrony Krajobrazu Kulturowego Mazur „Sadyba”, Kadzidłowo-Olszyn.

\footnotetext{
5 Dla przykładu w Edmonton (Kanada) obliczono, że każde z 12,8 mln drzew daje roczne korzyści w wy-
} miarze 74,73 USD, a koszty jego utrzymania w tym samym okresie wynoszą zaledwie 18,38 USD (TEEB 2011). 
Cities and Climate Change: An Urgent Agenda, 2010, Międzynarodowy Bank Odbudowy i Rozwoju / Bank Światowy, Waszyngton.

The Fiscal Year 2015 Executive Budget, http://www1.nyc.gov/html/omb/downloads/pdf/sum5_14.pdf (dostęp 25 marca 2018).

Główny Urząd Statystyczny, Bank Danych Lokalnych, https://bdl.stat.gov.pl/BDL/start (dostęp 5 lipca 2017).

Hermann B., 2013, Czynniki kształtujące wartość nieruchomości w kontekście dokumentów planistycznych, konferencja „Skutki finansowe planowania przestrzennego - konsekwencje dla rozwoju”, Poznań.

Kosmala M., 2007, Rola i znaczenie lasów miejskich w życiu mieszkańców miast, [w:] Oleksiejuk E., Jankowska A. (red.), Zieleń miejska - naturalne bogactwo miasta. Lasy w miastach Unii Europejskiej - zasady gospodarowania i ochrona, Polskie Zrzeszenie Inżynierów i Techników Sanitarnych, Toruń.

Łukasiewicz A., Łukasiewicz S., 2011, Rola i kształtowanie zieleni miejskiej, Wydawnictwo Naukowe UAM, Poznań.

Malczyk T., 2012, Zieleń w krajobrazie terenów inwestycyjnych, Oficyna Wydawnicza PWSZ w Nysie, Nysa. Montgomery C., 2015, Miasto szczęśliwe, Wysoki Zamek, Kraków.

New York City Street Tree Map, https://tree-map.nycgovparks.org/ (dostęp 15 lutego 2017).

Open Tree Map, https://www.opentreemap.org/ (dostęp 15 lutego 2017).

Senetra A., 2010, Wptyw metodyki oceny walorów krajobrazowych na wyniki szacowania nieruchomości, "Acta Scientiarum Polonorum. Administatio Locorum” 9(2).

Szczepanowska H.B., 2009, Metoda wyceny wartości drzew na terenach zurbanizowanych dla warunków polskich, Instytut Gospodarki Przestrzennej i Mieszkalnictwa, Warszawa.

Szczepanowska H.B., 2012, Miejsce terenów zieleni w strukturze zintegrowanego projektowania, zarządzania i oceny ekologicznej inwestycji miejskich, „Człowiek i Środowisko” 36(1-2).

Szczepanowska H.B., 2015, Drzewa w mieście - zielony kapitał wartości i usług ekosystemowych, „Człowiek i Środowisko" 39(2).

Szczepanowska H.B., Sitarski M., 2015, Drzewa - zielony kapitat miast. Jak zwiększyć efektywność pracy drzew?, Instytut Gospodarki Przestrzennej i Mieszkalnictwa, Warszawa.

TEEB, 2011, Poradnik TEEB dla miast: ustugi ekosystemów w gospodarce miejskiej, wydanie polskie: Fundacja Sendzimira, Kraków.

Wolf K.L., 2006, Roadside urban trees - balancing safety and community values, „Arborist News” December.

Zydroń A., Kayzer D., Zbierska A., Szczepański P., 2016, Czynniki wptywające na wartość nieruchomości niezabudowanych przeznaczonych na cele budowlane, „Studia i Prace Wydziału Nauk Ekonomicznych i Zarządzania Uniwersytetu Szczecińskiego” nr 42, t. 2.

http://www.mapadrzew.pl/warszawa/map/ (dostęp 22 marca 2018).

https://bdl.stat.gov.pl/BDL/start (dostęp 21 marca 2018).

https://opendata.cityofnewyork.us/ (dostęp 23 marca 2018). 